Article

\title{
Does Suburbanization Cause Ecological Deterioration? An Empirical Analysis of Shanghai, China
}

\author{
Hefeng Wang ${ }^{1,2, *}$, Yishao Shi ${ }^{3}$, Anbing Zhang ${ }^{1,2}$, Yuan Cao ${ }^{1}$ and Haixin Liu ${ }^{1,2}$ \\ 1 School of Mining and Geomatics, Hebei University of Engineering, Handan 056021, Hebei, China; \\ zhanganbing@hebeu.edu.cn (A.Z.); caoyuan@hebeu.edu.cn (Y.C.); gislhx@hebeu.edu.cn (H.L.) \\ 2 Collaborative Innovation Center of Comprehensive Development and Utilization of Coal Resource, \\ Handan 056021, Hebei, China \\ 3 College of Surveying and Geo-Informatics, Tongji University, Shanghai 200092, China; \\ shiyishao@tongji.edu.cn \\ * Correspondence: wanghefeng@hebeu.edu.cn
}

Academic Editors: Yichun Xie, Xinyue Ye and Clio Andris

Received: 2 November 2016; Accepted: 11 January 2017; Published: 16 January 2017

\begin{abstract}
Suburbanization in the US largely occurred to solve various urban problems; however, it has also caused many issues, such as the decline of central urban areas, the waste of land resources, and the deterioration of ecological environments in the suburbs. Therefore, the study of suburbanization has received considerable attention in academia. Scholars have argued that suburbanization leads to ecological deterioration. To examine this viewpoint, the authors analyzed spatial-temporal changes in the ambient environment, the soil environment, the water environment, and other ecological environments, as well as carbon emissions of the central urban areas and the suburbs, in the suburbanization process exemplified by Shanghai. The results showed that suburbanization indeed caused many changes in ecological and environmental quality, but that the overall environmental quality in the suburbs of Shanghai remained better than that in the central urban area. It is important not to exaggerate the negative impact of suburbanization in metropolitan areas on the quality of the surrounding ecological environments. However, great attention must be given to controlling the diffusion of pollutants resulting from industrial and population suburbanization. It is also crucial to continue strengthening ecological environmental remediation, improvement, and recovery in the central urban area, and to comprehensively promote the coordinated development of agricultural modernization, industrial aggregation, low-carbon urbanization, and ecological sustainability, in both urban and rural areas.
\end{abstract}

Keywords: suburbanization; ecological environment; empirical analysis

\section{Introduction}

Traditionally, suburbanization is defined as a centrifugal movement from central urban areas to peripheral suburbs, followed by a concentric movement of populations and industrial economic activities to central urban areas, which is a new phase of urbanization [1,2]. Currently, the "combination of non-central population and economic growth with urban spatial expansion", is widely recognized as a global view of suburbanization, illustrating that these wider processes ("postsuburbanization" of the periphery and the idea of linear peripheralization) are in fact a planetary phenomenon $[3,4]$. The upsurge in the suburbanization of some metropolises in developed countries appeared in the 1950s and 1960s. However, some large Chinese cities have shown strong momentum towards suburbanization in recent years. For example, during the 10th Five-year Plan, Beijing's general urban plan proposed that urban spatial structure adjustment should be driven by the development of 
new towns. The plan was aimed at promoting the balanced development of employment and residence, by means of initially establishing high quality, flawless, and convenient public service facilities and infrastructure, which was meant to enhance the attractiveness of new towns so that they could then be built into livable model cities. The Beijing Municipal Planning Commission announced 11 new town planning schemes, including Yizhuang, Tongzhou, Shunyi, Changping, Daxing, Fangshan, Huairou, Mentougou, Miyun, Pinggu and Yanqing, on 6 November 2007. The total population of the 11 new towns will reach 5.05-6.05 million in 2020. Furthermore, the gross population of the key new towns of Yizhuang, Tongzhou, and Shunyi, will reach 2.5 million. Public transport in Yizhuang will increase by 30 percent, the per capita GDP of Tongzhou will exceed 10,000 US dollars, and the tertiary industry of Shunyi will increase by more than $60 \%$. The industrial suburbanization of Shanghai has accelerated since 1990; both the population and the residential suburbanization have rapidly progressed. Since 2010, the main emphasis of urban construction in Shanghai has specifically shifted towards the suburbs, and the city has focused on building new suburban towns, enhancing their scale economies and promoting the integration of industrialization and urbanization [5]. Before 2020, the integration of industrialization and urbanization, and urban and rural infrastructural systems, will develop in new suburban towns, which will become an important part of the Yangtze River Delta urban agglomerations and form functional complements, location development, and close contact with the urban central areas [6]. However, urban suburbanization also brings negative effects to the ecological system of the urban fringe or suburbs, and the ecological environment in the suburbs has significantly changed. Many high-quality cultivated land and vegetable land areas have been constantly occupied, and the agricultural land area has continuously decreased in the suburbs. Moreover, there are unexpected problems, such as advance land acquisition, blind enclosure, land levy, illegal transfer, and land that has not been effectively utilized in the enterprise suburbanization transfer process, due to improper planning and management. Due to the suburbanization process, the integrity of the original space is destroyed, the ecological landscape is increasingly "fragmented", and the green space system is reduced, which exacerbates ecological fragility and weakens the green space's adjustment function in the overall ecological environment of cities. In addition, suburbanization will inevitably increase the population, as well as industrial and commercial immigration. However, environmental protection goals are difficult to meet; thus, suburbanization will also bring more serious environmental pollution. For example, discharges of domestic sewage and industrial wastewater will lead to water and soil pollution, and increased commuting distances will inevitably bring an extension of bus lines and an increase in the number of vehicles, which will cause serious air pollution in the suburbs [7-9]. In response to this trend, the characteristics, dynamic mechanisms, existing problems, and planning strategies of suburbanization have become a popular subject in academic research [10-14].

Compared with developed countries, the government had more power to promote the concept of suburbanization during its implementation in China; then, market operations became consistent motivators for promoting the suburbanization process and to create a form of expression [15]. Industrial suburbanization preceded suburbanization of the population, largely because there were many different types and levels of development zones in the urban fringe and suburbs after the 1980s [16]. The shift towards industrial suburbanization gradually drove population, commercial, and residential suburbanization. However, because the infrastructure and the convenience service industry were out of sync in the suburbs, the pulling effect of industrial suburbanization was insignificant, and both population and commercial suburbanization lagged behind $[17,18]$. In addition, several outstanding problems were exposed during the process of suburbanization. In particular, the extensive sprawl of urban development caused a lack of urban land use and obvious bottlenecks of land, water, and energy resources, as well as transportation and the environment [19-21]. Therefore, many scholars tend to link the expansion of suburbanization with urban sprawl, and they blame the excessive consumption of resources, the deterioration of the ecological environment, and the aggravation of social conflicts on unfettered suburbanization, instead of reflecting on patterns and paths of economic development [22,23]. Additionally, many scholars often ignore the differences in national development 
conditions, blindly worship the American development model, and consider the above-mentioned problems to be the inevitable product of suburbanization. This approach allows those in power to shirk their responsibilities for decision-making failures, instead of investigating the reasons underlying the differences in national development conditions and the context of planning and administration. For example, there are frequent complaints that the construction of new towns in Chinese metropolises was too hasty, that there were too many urban functions required, and that the morphological change was too fast. In fact, the main issue was incomplete urban development [24]. Others have complained about the wide roads, vast squares, and huge stretches of greenbelt that have been built; however, the realistic regret is that there are too few greenbelts and a shortage of small squares [25]. The United States is one of the most typically developed Western countries which has witnessed suburbanization since World War II; the country's suburbanization is based on the infinite spread of suburban land. This spread leads to many problems, including central city recession, ecological environment destruction, urban structure disintegration, and stratum separation [26]. China remains in a rapid urbanization stage. Under the joint action of land ownership and the government, Chinese suburbanization presents different characteristics; urban centers continue to house the main functions of the city and are prosperous compared to the suburbs, but suburbanization alleviates the large cities' problems, such as population density, traffic congestion, and housing tensions. Certain problems are certainly associated with suburbanization, such as the phenomenon of ghost towns, empty cities, the waste of land resources, and the fact that planning targets are unachievable, but these problems are those of developing metropolises and should be solved in the development process $[27,28]$. Particularly in the face of ecological environment problems, a handful of scholars continue to excessively glamorize or exaggerate the hazards of suburbanization, even positing that suburbanization is leading to ecological disasters [29,30]. Will Chinese suburbanization cause ecological deterioration, as it did in the United States? In this paper, we use Shanghai's suburbanization as an example. Based on a statistical and spatial data time series, we attempt to apply statistical analysis, estimation methods, and GIS technology, in order to investigate the spatial-temporal changes of the ecological environmental indicators in the central urban areas and suburbs. We comparatively analyze the evolutionary features or rules of the indicators from the different scales in the suburbanization process. We then discuss and examine the above viewpoint. References to existing research and data availability and operability, $\mathrm{SO}_{2}$, $\mathrm{NO}_{2}$, and $\mathrm{PM}_{10}$ indicators, soil environmental quality, water environmental quality, carbon sources, and carbon sinks, were chosen to analyze the ecological environment, because the suburbanization process can cause atmospheric, water, soil, and other ecological factor effects. Additionally, the ecological environment is affected by the carbon emissions of the migration and immigration of urban population mobility, production services, living consumption, and urban construction.

\section{Materials and Methods}

\subsection{Study Area}

Shanghai is located at the mouth of the Yangtze River and is connected to the two provinces of Jiangsu and Zhejiang. It is China's largest industrial and commercial city, and is a famous international metropolis that has become an important economic center in China. It is also the primary city of the Yangtze River Delta. Shanghai is being built into an international economic, financial, trade, and shipping center. Since China's reform, its society and economy have developed rapidly. By 2013, the GDP of Shanghai had reached approximately 2.16 trillion yuan, and the urban population accounted for over $89 \%$ of the total population; its urbanization level was ranked the first in China. Shanghai was one of the first cities to suburbanize in China. The suburbanization process is affected by government-dominated, market-oriented forces, the establishment of a land market, and economic restructuring; additionally, the government continues to play a direct role. In recent decades, the government of Shanghai has undertaken a development strategy of suburbanization, such as industrial suburbanization transfer, development zone construction, new town construction, new housing 
development, industrial restructuring, and infrastructure construction. In the context of economic, government, and land policies, industrial suburbanization has largely been achieved, the process of population, residential, and commercial suburbanization has accelerated in Shanghai, and development trends that integrate industries and new towns can be observed in the suburbs. Function and control have also improved in the central city. However, certain phenomena are occurring in the suburbs, such as industrial planning interrupting connections among the population, employment being separated from residences, low efficiency of land use, and challenges in protecting the ecological environment. Thus, Shanghai is a significant case study for understanding typical suburbanization.

\subsection{Data Sources}

The main data sources of this study are as follows: (1) the Shanghai Statistical Yearbook (1998-2014) [31-47]; (2) the Shanghai Bulletins of Environmental Quality (1998-2011) [48-61]; (3) the Shanghai Water Resources Bulletin $(2012,2013)$, the spatial distribution of the main rivers and conservancy-controlled districts in Shanghai [62,63]; (4) the report of Shanghai land quality monitoring (2009-2012) [64]; and (5) the Second Shanghai land survey database (2009) [65].

\subsection{Research Method}

\subsubsection{Statistical Analysis}

Statistical data indicate the size, structure, and levels of data, and are the basis of qualitative, positioning, and quantitative statistical analysis. The characteristics of changes in the natural and economic elements of a geographic area can be effectively reflected by a statistical data time-series comparison analysis. This traditional approach can be in-depth and clearly understood, thereby facilitating evaluation. Based on the statistical data time-series, we selected certain indicators of the ecological environment and used statistical comparison analysis to reveal the temporal and spatial changes in the ecological environment of the central urban areas and suburbs of Shanghai. The spatial distributions of certain indicators were displayed with GIS technology [66,67].

\subsubsection{Estimation Methods for Carbon Emissions}

\section{(1) Calculating carbon sources}

According to the definition of the Intergovernmental Panel on Climate Change (IPCC), a carbon source comprises carbon dioxide gas components from the earth's surface that are present in the atmosphere, or other substances that are transformed into carbon dioxide gas components through chemical processes in the atmosphere [68]. In this paper, a carbon source is defined as any process or activity that causes greenhouse gas emissions, and the magnitude can be expressed as the carbon dioxide equivalent (C-eq).

At present, there are many methods for estimating a carbon source; these include the actual measurement method, the material balance method, the emission factor method, and the department estimation method [69-72]. The results differ slightly when using the different methods. In the present study, the department estimation method was applied in order to calculate carbon emissions based on land use structure. This method is applicable to a study subject which has a known gross economic quantity, total population, unit energy consumption of economic quantity, per capita energy consumption quantity, and carbon emission factors. The formula is as follows:

$$
C E=(a \times X+b \times Y+c \times Z+d \times E) \times C E F
$$

where $C E$ is total carbon source, $X$ is value-added of the primary industry, $Y$ is value-added of the secondary industry, $Z$ is value-added of the tertiary industry, $E$ is household population in each district, $a$ is energy consumption per value-added of the primary industry, $b$ is energy consumption per value-added of the secondary industry, $c$ is energy consumption per value-added of the tertiary 
industry, $d$ is the coefficient of per capita energy consumption, and CEF is the comprehensive carbon emission factor (the value is $0.598 \mathrm{tC}$-eq/tons standard coal equivalent).

In this article, per unit value-added energy consumption for various industries in each district (county), is adopted as the average value for Shanghai. Per capita energy consumption is also adopted as the average value for Shanghai, and 0.678 tons per capita is the standard coal equivalent. Energy consumption per value-added unit of the primary industry, secondary industry, and tertiary industry, is $0.679,0.981$, and 0.418 tons' standard coal equivalents per ten thousand yuan, respectively.

(2) Calculating the carbon sink

The United Nations Framework Convention on Climate Change (UNFCC) defines a carbon sink as the processes, activities, or mechanisms of cleaning carbon dioxide from the atmosphere, and further describes the methods used for estimating different types of carbon sinks [73]. Carbon sinks in Shanghai come from arable land, forestland, aquaculture water surfaces, ponds, beaches and flats, reed land, and crops, which can be further grouped into four categories: forestland, crops, soil, and wetlands.

(i) Forestland carbon sink

The formula is as follows:

$$
H_{w}=0.627 \times S_{w}
$$

Here, $H_{w}$ is the carbon sink of garden green space, and $S_{w}$ is the forestland area.

Forestland in Shanghai consists of primarily young and middle-aged forest that has superior solid carbon abilities. Combining the research on the vegetation-based carbon sinks of forest, grassland, shrub, crops, and others, from 1981 to 2000 in China by Professor Fang Jing-yun et al., the annual solid carbon ability of forestland is approximately $0.53-0.65 \mathrm{tC}$-eq/ha [74]; therefore, $0.627 \mathrm{tC}$-eq/ha is the value adopted when calculating the carbon sink of forestland in Shanghai.

(ii) Crop carbon sink

The crop carbon sink $\left(H_{c}\right)$ assimilates $\mathrm{CO}_{2}$ from the atmosphere, releases $\mathrm{O}_{2}$, and synthetizes carbohydrates for the growth and development of crops by photosynthesis. The dry matter accumulation of crops reflects their assimilative capacity, and the carbon content of crops can then be calculated by determining the sum of the carbon assimilation of crops in their growing seasons. Crops are also fixed in terms of the amount of $\mathrm{CO}_{2}$ that they assimilate from the atmosphere. The formula for estimating carbon sinks $\left(H_{c}\right)$ in the growth and development periods of crops is as follows:

$$
H_{c}=\sum C_{i}=\sum C_{f} Y_{w} / H_{i}
$$

Here, $C_{i}$ is the carbon absorption of crop ' $i$ ' in its growth and development period, $C_{f}$ is the requirement of absorbent carbon for synthesizing the organic matter (dry mass) of crop ' $i$ ' (carbon sink rate), $Y_{w}$ is the economic output of crop ' $i$ ', and $H_{i}$ is the economic coefficient of crop ' $i$ '. The economic coefficients and carbon sink rates of the main crops are shown in Table 1 [75].

Table 1. Economic coefficients and carbon absorption of the main crops in Shanghai.

\begin{tabular}{cccccccccc}
\hline Item & Rice & Wheat & Corn & Sorghum & Millet & Potato & Soybean & Cotton & Groundnut \\
\hline$C_{f}$ & 0.45 & 0.40 & 0.40 & 0.35 & 0.40 & 0.70 & 0.34 & 0.10 & 0.43 \\
$H_{i}$ & 0.41 & 0.48 & 0.47 & 0.45 & 0.45 & 0.42 & 0.45 & 0.45 & 0.45 \\
\hline
\end{tabular}

According to the Statistical Yearbook of Shanghai, crop carbon sinks are subdivided into foodstuff carbon sinks $\left(C_{r}\right)$, grain carbon sinks $\left(C_{t}\right)$, and rape carbon sinks $\left(C_{b}\right)$, and are calculated as follows:

$$
H_{c}=\sum\left(C_{r}+C_{t}+C_{b}\right)
$$


Furthermore, considering the large amount of industrial subsidiary energy consumed in the manufacturing and transportation processes of fertilizer, agricultural machinery, pesticides and other supplies, researchers argue that because these elements of agricultural production release carbon in various production or energy consumption processes, they should also be viewed as producers of crop carbon sources. These factors are not considered in this paper; only carbon sinks in the crop growth process are calculated [76].

(iii) Soil carbon sink

The annual solid carbon-absorbing ability of soil is closely related to crop type, climate, soil properties, and the cropping system of the agricultural ecosystem; its value is approximately 0.095-1.143 tC-eq/ha [77,78]. This paper primarily considers the soil carbon sink in the agricultural ecosystem; thus, only the carbon sink of arable land is calculated. Because the main crop planted in Shanghai's arable land is rice, which involves using organic fertilizer and green manure and the incorporation of straw, the carbon sink capacity of the soil is high, and the carbon sink coefficient of soil reaches $1.12 \mathrm{tC}-\mathrm{eq} / \mathrm{ha}$. The formula is as follows:

$$
H_{E}=1.12 \times S_{E}
$$

Here, $H_{E}$ is the soil carbon sink, and $S_{E}$ is the area of arable land.

(iv) Wetland carbon sink

This article primarily considers carbon sinks of aquaculture water surfaces, ponds, rivers, lakes, beaches, flats, and reed land. The annual solid carbon-absorbing ability of wetlands is approximately 0.5-57.4 tC-eq/ha [78]. Related research by Mei X. et al. indicates that the annual solid carbon-absorbing ability of the reed zone is high in the Chongming eastern beach at the mouth of the Yangtze River [79]. The carbon sink coefficient of wetlands is $2.2 \mathrm{tC}$-eq/ha in the present study, and the formula is as follows:

$$
H_{L}=2.2 \times S_{L}
$$

Here, $H_{L}$ is the wetland carbon sink and $S_{L}$ is the area of the wetlands.

In summary, the formula for total carbon sinks is as follows:

$$
C T=H_{W}+H_{C}+H_{E}+H_{L}
$$

(3) Calculating the net carbon source

The net carbon sources of the districts (counties) in Shanghai are calculated using the following formula:

$$
N C E=C E-C T
$$

Here, NCE is net carbon source, $C E$ is total carbon source, and $C T$ is total carbon sink.

\section{Results}

\subsection{Comparative Analysis of Environmental Quality}

\subsubsection{Ambient Environmental Quality}

In recent years, the quality of the atmospheric environment in Shanghai has gradually improved. With the industrial suburbanization transfer, atmospheric pollution is gradually decreasing in the central urban areas, but is increasing and then decreasing in the suburbs. Acid rain has already become an important issue when considering the atmospheric environment. The air quality in the suburbs is significantly better than that in the central urban areas of Shanghai. In 1984, annual emissions of $\mathrm{SO}_{2}$, smoke, and dust in the central urban areas were 2.4 times, 2.7 times, and 3.3 times those in the suburbs 
in Shanghai, respectively. The annual daily mean concentration of $\mathrm{SO}_{2}\left(\mathrm{mg} / \mathrm{m}^{3}\right)$ in the central urban areas was nine times that in the suburbs, the annual daily mean concentration of $\mathrm{NO}_{\mathrm{x}}$ was 2.5 times that in the suburbs, and the annual daily mean concentrations of airborne particles and dust fall were 1.2 times and two times those in the suburbs, respectively. The mean industrial waste gas emission in the central urban areas was $1556.1 \mathrm{t} / \mathrm{km}^{2}$ per year, equivalent to 66.5 times the mean in the suburbs, and 17.9 times that in Shanghai (including the suburbs) [80].

Since the mid-1980s, due to the gradual progress of manufacturing suburbanization, air-quality distribution patterns have undergone significant changes in the suburbs. According to statistical analyses, by the year 2010, annual emissions of industrial waste gas, industrial smoke, and industrial waste $\mathrm{SO}_{2}$ gas, in the central urban areas were approximately 1.2 times, 1.1 times and 2.1 times those in the suburbs, respectively. The annual daily mean concentrations of $\mathrm{SO}_{2}$ and $\mathrm{NO}_{2}$ in the central urban areas were approximately 0.8 times and 1.2 times those in the suburbs, respectively; the mean concentration of $\mathrm{PM}_{10}$ in the central urban areas approximated that in the suburbs, and the frequency of acid rain was approximately 0.8 times that in the suburbs (Table 2). Industrial waste gas, smoke, and the intensity of $\mathrm{SO}_{2}$ emission in the central urban areas were 25.6 times, 23.8 times and 38.2 times the mean in the suburbs, respectively. Compared to 1997, the ambient air quality in the central urban areas has improved, but the annual daily mean concentrations of $\mathrm{SO}_{2}, \mathrm{NO}_{2}, \mathrm{PM}_{10}$, and unit area pollutant emissions intensity, has remained higher than corresponding concentrations in the suburbs from 1997 to 2010. Ambient air quality in the suburbs was better than that in the central urban areas.

Table 2. Change in ambient environmental quality in Shanghai from 1997 to 2010.

\begin{tabular}{|c|c|c|c|c|c|c|c|c|}
\hline \multirow[t]{2}{*}{ Year } & \multicolumn{2}{|c|}{$\begin{array}{c}\text { Daily Mean } \\
\text { Concentration of } \mathrm{SO}_{2} \\
\left(\mathrm{mg} / \mathrm{m}^{3}\right)\end{array}$} & \multicolumn{2}{|c|}{$\begin{array}{c}\text { Daily Mean } \\
\text { Concentration of } \mathrm{NO}_{2} \\
\left(\mathrm{mg} / \mathrm{m}^{3}\right)\end{array}$} & \multicolumn{2}{|c|}{$\begin{array}{c}\text { Daily Mean } \\
\text { Concentration of } \mathrm{PM}_{10} * \\
\left(\mathrm{mg} / \mathrm{m}^{3}\right)\end{array}$} & \multirow{2}{*}{$\begin{array}{l}\text { Precipitation } \\
\text { pH Value }\end{array}$} & \multirow[t]{2}{*}{$\begin{array}{l}\text { Frequency of } \\
\text { Acid Rain (\%) }\end{array}$} \\
\hline & $\begin{array}{c}\text { Central } \\
\text { Urban Areas }\end{array}$ & Suburbs & $\begin{array}{c}\text { Central } \\
\text { Urban Areas }\end{array}$ & Suburbs & $\begin{array}{c}\text { Central } \\
\text { Urban Areas }\end{array}$ & $\begin{array}{l}\text { Suburbs } \\
\text { (Country) }\end{array}$ & & \\
\hline 1997 & 0.068 & 0.008 & 0.105 & 0.028 & 0.231 & 0.167 & 5.71 & 11.00 \\
\hline 1998 & 0.053 & 0.006 & 0.102 & 0.029 & 0.215 & 0.147 & 5.58 & 15.10 \\
\hline 1999 & 0.044 & 0.005 & 0.099 & 0.033 & 0.168 & 0.152 & 5.63 & 12.10 \\
\hline 2000 & 0.045 & 0.004 & 0.090 & 0.032 & 0.156 & 0.128 & 5.19 & 26.00 \\
\hline 2001 & 0.043 & 0.017 & 0.063 & 0.035 & 0.100 & / & 5.20 & 25.20 \\
\hline 2002 & 0.035 & 0.017 & 0.058 & 0.039 & 0.108 & / & 5.39 & 10.90 \\
\hline 2003 & 0.043 & 0.026 & 0.057 & 0.040 & 0.097 & / & 5.21 & 16.70 \\
\hline 2004 & 0.055 & 0.034 & 0.062 & 0.038 & 0.099 & 0.095 & 4.92 & 32.70 \\
\hline 2005 & 0.061 & 0.031 & 0.061 & 0.038 & 0.088 & 0.087 & 4.93 & 40.00 \\
\hline 2006 & 0.055 & 0.041 & 0.051 & 0.047 & 0.086 & 0.085 & 4.73 & 56.40 \\
\hline 2007 & 0.055 & 0.048 & 0.054 & 0.050 & 0.088 & 0.083 & 4.55 & 75.60 \\
\hline 2008 & 0.051 & 0.044 & 0.056 & 0.046 & 0.084 & 0.078 & 4.39 & 79.20 \\
\hline 2009 & 0.035 & 0.032 & 0.053 & 0.045 & 0.081 & 0.075 & 4.66 & 74.90 \\
\hline 2010 & 0.029 & 0.030 & 0.050 & 0.042 & 0.079 & 0.076 & 4.66 & 73.90 \\
\hline
\end{tabular}

\subsubsection{Soil Environmental Quality}

The analysis and evaluation of soil environmental quality in Shanghai (primarily including indicators of heavy metals, organochlorine pesticides, polycyclic aromatic hydrocarbons, and agricultural nutrient elements), by the Shanghai Institute of Geological Survey, show that the soil environmental quality is generally good and that areas with better than class II soil account for $94.95 \%$ of the total area. The exception is central urban areas and the surrounding industrial zones (Figure 1), in which class I soil is primarily distributed in the three Chongming islands and the southeast of Shanghai; class III and superclass III soil are distributed in the central urban areas. In terms of land use, the class I and class II soil-distribution areas largely consist of the arable land in Shanghai, and those of class III and superclass III primarily comprise of the urban and rural industrial land, mining land, and residential areas. In other words, the soil environmental quality of the suburbs is significantly better than that of central urban areas. The major reason for heavy metal pollution in the soil is the 
uncontrolled sewage in the urban and rural areas, industry, mining, and residential lands in the central urban areas of Shanghai.

Due to historical factors, a large amount of wastewater, gas waste, and waste emissions from the production processes that result from inferior environmental protection facilities, have caused serious threats to the soil environment and to residents' health in certain older industrial enterprises, that are concentrated in the Shanghai distribution area. As many polluting enterprises gradually moved out of the central urban areas, the remaining contaminated land became known as "brownfields" [81]. This characterization was particularly accurate for chemical industrial lands because of the higher concentrations of heavy metals that easily enter the atmosphere and water, causing atmospheric pollution, surface water pollution, ecosystem degradation, and other secondary ecological problems. These lands can be synthetically utilized through recovery and remediation.

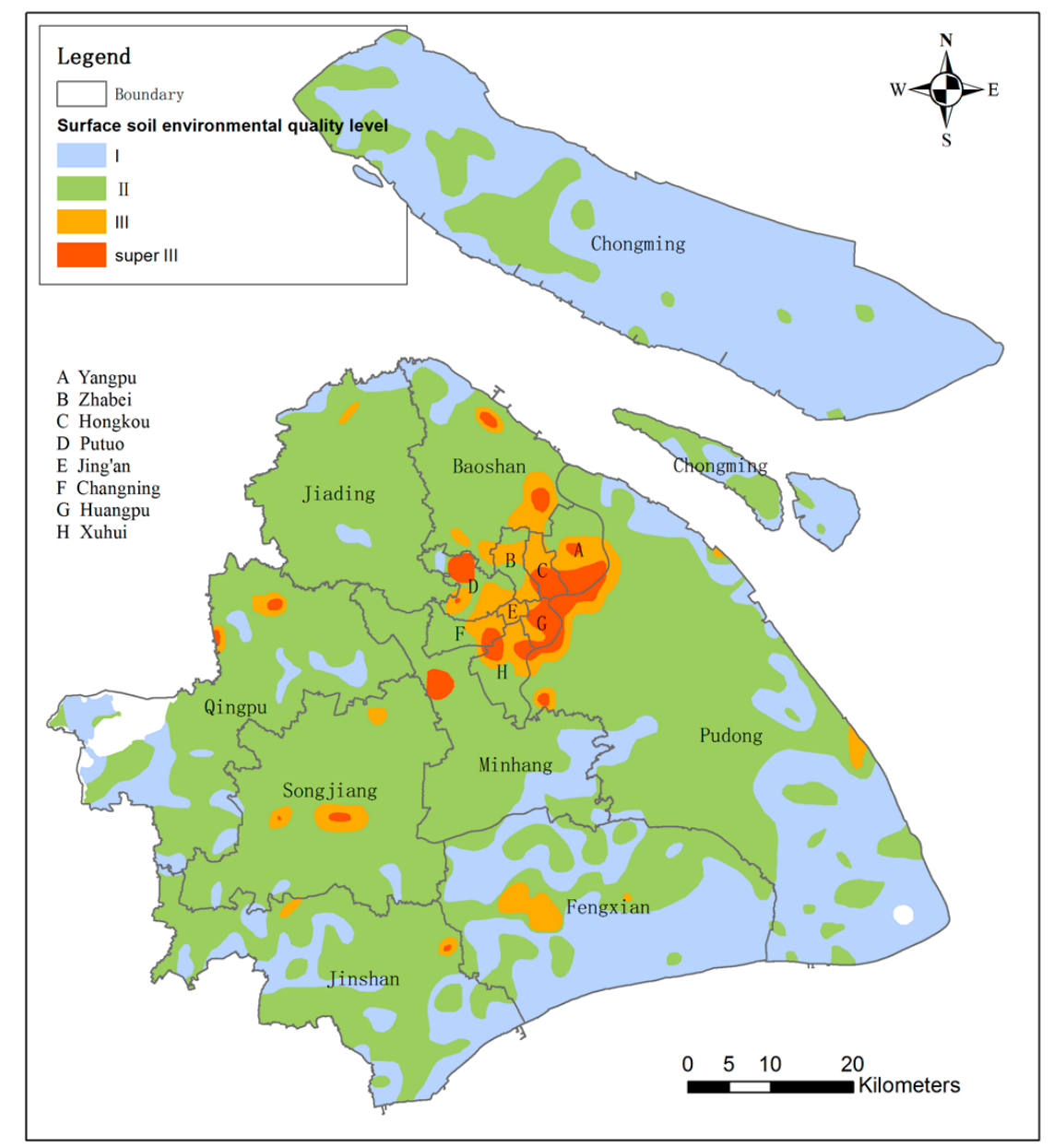

Figure 1. Synthesized results of the evaluation of Shanghai surface soil environmental quality. Source: The figure was adapted from the report of Shanghai land quality monitoring (2009-2012) [34].

Table 3 shows that from 1996-2000, in parallel with the increasing level of urbanization and the transfer of manufacturing to the suburbs, the soil pollution of Shanghai appears to follow a worsening trend; the soil pollution rates of Pudong, Baoshan, Jiading, Minhang, and other suburbs, reach approximately $30 \%-52 \%$, values which are much higher than other districts (country) in the outer suburbs. 
Table 3. Comprehensive assessment results of soil environmental quality in the suburbs from 1996 to 2000 .

\begin{tabular}{ccccccc}
\hline $\begin{array}{c}\text { Districts } \\
\text { (County) }\end{array}$ & $\begin{array}{c}\text { Average Comprehensive } \\
\text { Pollution Index }\end{array}$ & $\begin{array}{c}\text { Good } \\
\mathbf{( \% )}\end{array}$ & $\begin{array}{c}\text { Safe } \\
\mathbf{( \% )}\end{array}$ & $\begin{array}{c}\text { Light } \\
\text { Pollution (\%) }\end{array}$ & $\begin{array}{c}\text { Medium } \\
\text { Pollution (\%) }\end{array}$ & $\begin{array}{c}\text { Heavy } \\
\text { Pollution (\%) }\end{array}$ \\
\hline Minhang & 1.005 & 9.09 & 60.61 & 21.21 & 0 & 9.09 \\
Jiading & 1.039 & 3.90 & 59.74 & 33.77 & 2.59 & 0 \\
Baoshan & 1.119 & 2.86 & 45.71 & 48.57 & 0 & 0 \\
Pudong & 1.209 & 12.00 & 36.00 & 40.00 & 0 & 0 \\
Nanhui & 0.947 & 4.17 & 66.67 & 29.16 & 0 & 0 \\
Qingpu & 0.871 & 11.69 & 76.62 & 10.39 & 0 & 0 \\
Jinshan & 0.769 & 0 & 100.00 & 0 & 0 & 0 \\
Fengxian & 0.724 & 21.43 & 78.57 & 68.97 & 17.24 & 0 \\
Songjiang & 0.891 & 13.79 & 6.69 & 0 \\
Chongming & 0.743 & 60.87 & 30.44 & 8.69 & 0 \\
\hline
\end{tabular}

Source: Soil-sampling test results from the Shanghai Environmental Protection Bureau during the 9th Five-year Plan.

\subsubsection{Water Environmental Quality}

Water environmental quality is one of the most important indicators of regional ecological environmental quality. Shanghai is one of 36 cities facing major shortages of water quality in China; local water resources are polluted, and the water quality is generally that of the inferior class II, which is difficult to improve in the short term. The results of the evaluation of surface water quality by the Shanghai Environmental Protection Department in 2013, show that the water quality of $719.8 \mathrm{~km}$ of 16 major Shanghai rivers ranked from class II to inferior class V, during the year. The water quality is better in class III, with a length of approximately $210.6 \mathrm{~km}$, which accounts for $29.2 \%$ of the total river length evaluation. Class IV has a length of approximately $170.6 \mathrm{~km}$ and accounts for $23.7 \%$ of the total river length evaluation. Class V measures $63.1 \mathrm{~km}$ and accounts for $8.8 \%$ of the total river length evaluation. Finally, inferior class V is approximately $275.6 \mathrm{~km}$, accounting for $38.3 \%$ of the total river length evaluation. The main water pollutants are organic pollutants, and the main super-standard items are ammonia and the permanganate index. Compared to 2012, the proportions of the lengths of the 16 major rivers are almost the same.

In 2013, the comprehensive results of an evaluation of 14 water quality control districts in Shanghai showed that the water quality of the Chongming island district was ranked as class III. The results of the Hengsha island, Taibei, Tainan, and Shangta districts, were class IV; those of the Diannan, Punandong, and Pudong districts, were class $\mathrm{V}$, and those of the other districts ranked as the inferior class V (Table 4, Figure 2).

In 2013, the water quality of the backbone channels in the central urban areas of Shanghai was ranked as being between class V and the inferior class V. Compared to 2012, water quality in the central urban areas had improved: the five-day biochemical oxygen demand, the mean ammonia concentration, the mean dissolved oxygen concentration, and the permanganate index, decreased by $26.3 \%, 16.2 \%, 11.4 \%$, and $9.0 \%$, respectively, whereas the chemical oxygen demand (COD) remained unchanged. Thus, water with a class II-III quality is entirely distributed in the suburbs, and the overall water quality in the suburbs is superior to that in central urban areas.

Table 4. Water quality of conservancy-controlled districts in Shanghai in 2013.

\begin{tabular}{lcccc}
\hline Water Quality Types & Class III & Class IV & Class V & Inferior Class V \\
\hline $\begin{array}{l}\text { Water conservancy- } \\
\text { controlled districts }\end{array}$ & $\begin{array}{c}\text { Chongming island } \\
\text { district }\end{array}$ & $\begin{array}{c}\text { Districts of } \\
\text { Hengsha island, } \\
\text { Taibei, Tainan and } \\
\text { Shangta }\end{array}$ & $\begin{array}{c}\text { Districts of } \\
\text { Diannan, Pudong } \\
\text { and Punandong }\end{array}$ & $\begin{array}{c}\text { Districts of Changxing } \\
\text { island, Dianbei, } \\
\text { Jiabaobei, Punanxi, } \\
\text { Qingsong and Wunnan }\end{array}$ \\
\hline
\end{tabular}




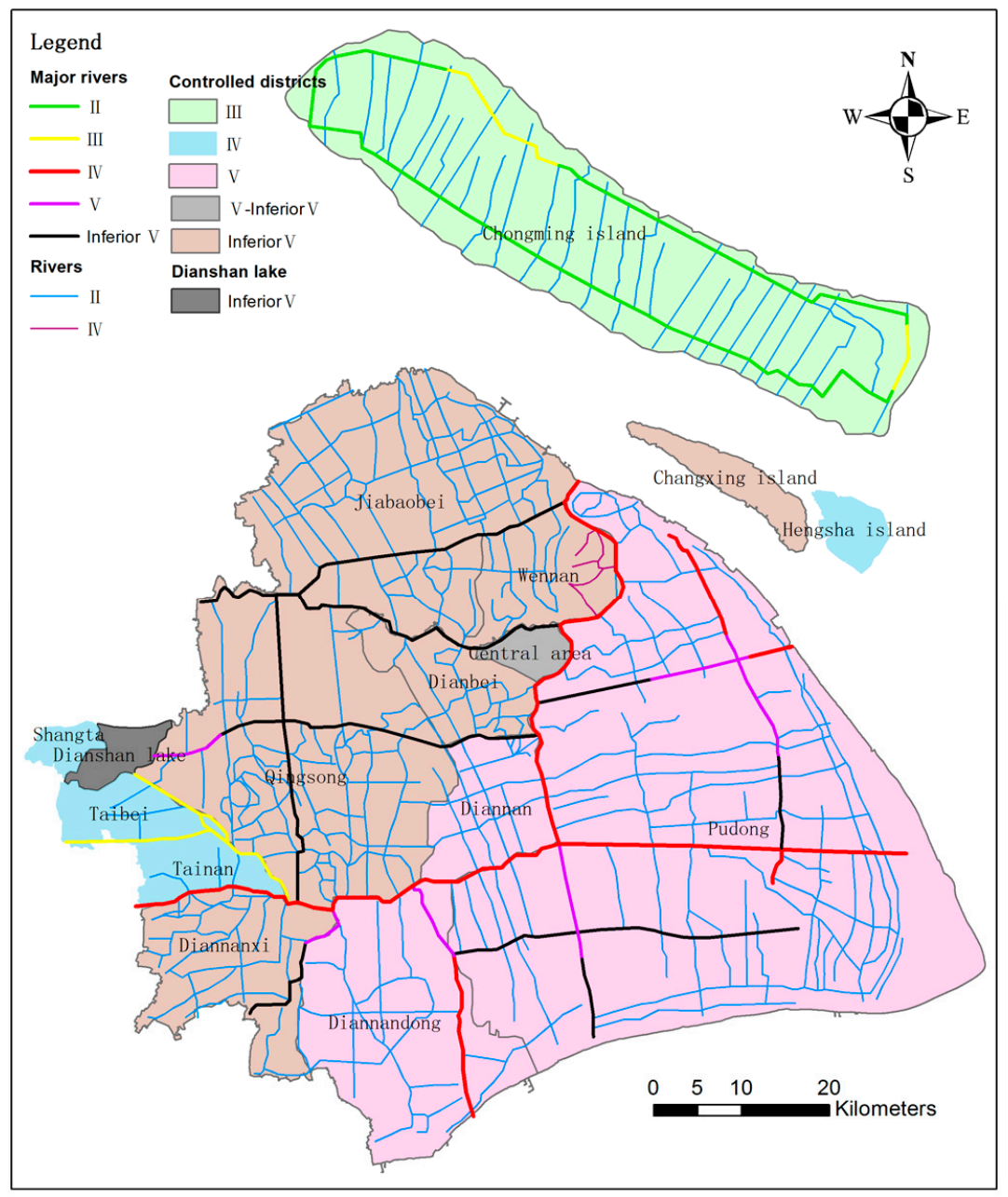

Figure 2. Comprehensive water quality evaluation of the main rivers and lakes in Shanghai in 2013.

\subsection{Comparative Analysis of Carbon Emissions}

Carbon emissions caused by land use activities are the major components of the total number of economic and social activities, and have become the second largest source of greenhouse gas emissions. When applying the carbon emission algorithm, per capita carbon emissions in the central urban areas and suburbs are computed, based on land use structure.

The calculated results (Table 5) are as follows: (1) the total carbon sources of the Pudong, Minhang, Songjiang, and Yangpu, districts are relatively high, whereas the sources of other districts are relatively low; (2) The total carbon sinks of Chongming, Qingpu, Jinshan, Fengxian, Songjiang, and other suburbs are larger, whereas those of the central urban areas are smaller; (3) With respect to per capita carbon emissions by the registered population, those of the central urban areas are generally lower than those in the suburbs, whereas those of Minhang, Pudong, Songjiang, Qinpu, and Jiading, are higher (Figure 3); (4) In terms of net carbon source per unit area, the central urban areas are generally higher than the suburbs, and the core areas are overall much higher than the peripheries of the central urban areas. Additionally, the periphery of the central urban areas is higher than the inner suburbs, the inner suburbs are higher than the outer suburbs, and the features show a diminishing trend gradient (Figure 4); Finally, (5) with respect to net carbon source per unit GDP, there is no obvious law of distribution. Both high-value districts (Luwan and Yangpu), and low-value districts (Hongkou and Changning), exist in the central urban areas, and the net carbon sources per unit GDP of Minhang, Songiiang, Fengxian, Qingpu, Jinshan, and other suburbs, are higher, whereas those of Huangpu, 
Putuo, and other central urban areas, are relatively low. Those of Pudong, Jiading, Xuhui, Jing'an, and other districts, are in the middle level.

Table 5. Carbon sources and carbon sinks of districts (county) in Shanghai in 2009.

\begin{tabular}{|c|c|c|c|c|c|c|c|}
\hline \multicolumn{2}{|c|}{ Districts (County) } & $\begin{array}{l}\text { Carbon } \\
\text { Source } \\
\text { (tC-eq) }\end{array}$ & $\begin{array}{l}\text { Carbon } \\
\text { Sink } \\
\text { (tC-eq) }\end{array}$ & $\begin{array}{c}\text { Net Carbon } \\
\text { Source } \\
\text { (tC-eq) }\end{array}$ & $\begin{array}{l}\text { Per Capita Carbon } \\
\text { Emission } \\
\text { (tC-eq/Per Capita) }\end{array}$ & $\begin{array}{c}\text { Unit Area Net } \\
\text { Carbon Source } \\
\left(\mathrm{tC}-\mathrm{eq} / \mathrm{km}^{2}\right)\end{array}$ & $\begin{array}{l}\text { Unit GDP Net } \\
\text { Carbon Source } \\
\text { (tC-eq } 10^{8} \text { Yuan) }\end{array}$ \\
\hline \multirow{9}{*}{$\begin{array}{c}\text { Central } \\
\text { areas }\end{array}$} & Putuo & $2,743,902.44$ & 4918.03 & $2,738,984.41$ & 3.14 & $49,954.12$ & 5496.11 \\
\hline & Yangpu & $7,134,146.34$ & 4918.03 & $7,129,228.31$ & 6.56 & $117,392.20$ & 9208.75 \\
\hline & Xuhui & $5,121,951.22$ & 4918.03 & $5,117,033.19$ & 5.65 & $93,444.73$ & 6145.41 \\
\hline & Zhabei & $2,926,829.27$ & 4918.03 & $2,921,911.24$ & 4.23 & $99,860.26$ & 7575.02 \\
\hline & Luwan & $2,074,434.54$ & 4818.03 & $2,069,616.51$ & 6.75 & $257,095.22$ & $18,683.91$ \\
\hline & Huangpu & $4,024,390.24$ & 4918.03 & $4,019,472.21$ & 6.67 & $323,889.78$ & 5492.28 \\
\hline & Jing'an & $1,097,560.98$ & 4918.03 & $1,092,642.94$ & 3.54 & $143,391.46$ & 7039.77 \\
\hline & Changning & $2,012,195.12$ & 4918.03 & $2,007,277.09$ & 3.27 & $52,409.32$ & 3985.94 \\
\hline & Hongkou & $1,280,487.80$ & 4918.03 & $1,275,569.77$ & 1.61 & $54,325.80$ & 1422.04 \\
\hline \multirow{4}{*}{$\begin{array}{l}\text { Inner } \\
\text { suburbs }\end{array}$} & Pudong & $27,804,878.05$ & $206,557.38$ & $27,598,320.67$ & 10.14 & $22,800.80$ & 6897.18 \\
\hline & Minhang & $11,890,243.90$ & $39,344.26$ & $11,850,899.64$ & 12.57 & $31,964.67$ & 9586.20 \\
\hline & Jiading & $4,390,243.90$ & $137,704.92$ & $4,252,538.98$ & 7.73 & 9161.01 & 6021.46 \\
\hline & Baoshan & $4,207,317.07$ & $54,098.36$ & $4,153,218.71$ & 4.81 & $15,326.10$ & 4548.73 \\
\hline \multirow{5}{*}{$\begin{array}{c}\text { Outer } \\
\text { suburbs }\end{array}$} & Fengxian & $3,658,536.59$ & $270,491.80$ & $3,388,044.78$ & 6.53 & 4928.85 & 7895.88 \\
\hline & Songjiang & $6,585,365.85$ & $275,409.84$ & $6,309,956.02$ & 11.28 & $10,418.66$ & 8335.92 \\
\hline & Jinshan & $2,743,902.44$ & $511,475.41$ & $2,232,427.03$ & 4.32 & 3809.28 & 7151.78 \\
\hline & Chongming & $1,829,268.29$ & $1,042,622.95$ & $786,645.34$ & 1.14 & 663.56 & 4609.70 \\
\hline & Qingpu & $4,390,243.90$ & $309,836.07$ & $4,080,407.84$ & 8.88 & 6088.89 & 7822.87 \\
\hline
\end{tabular}

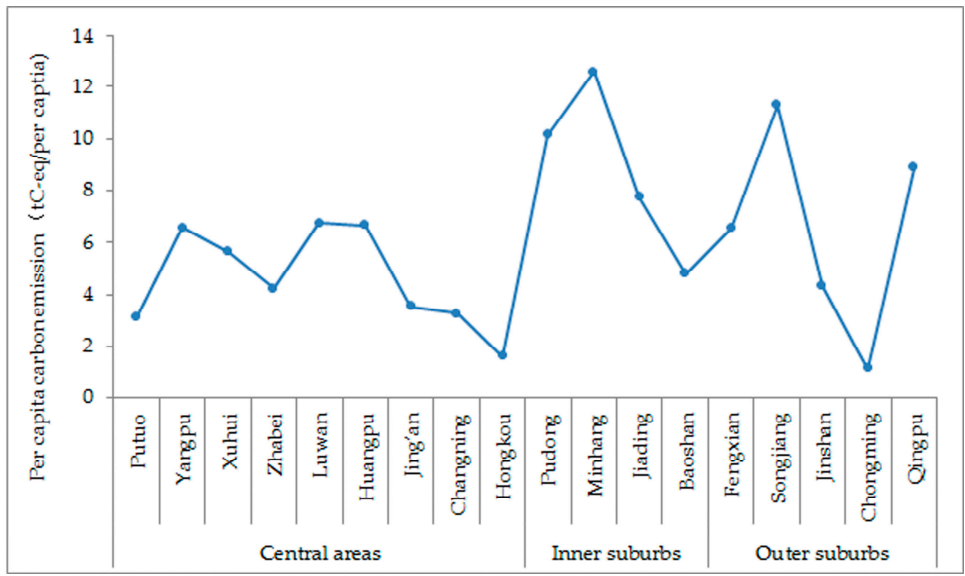

Figure 3. Per capita carbon emission of districts (county) in 2009.

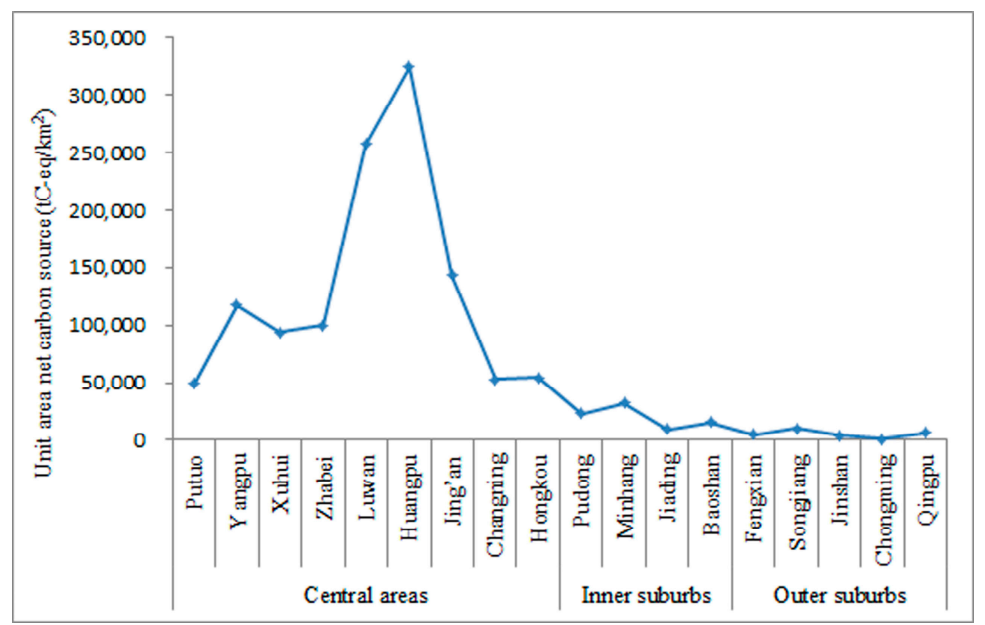

Figure 4. Net carbon source per unit area of districts (county) in 2009. 


\section{Discussion}

Due to a dense population, traffic congestion, a higher building density, high energy consumption, multiple pollution sources, and a high emission of pollutants, the environmental quality in the central urban areas is usually worse than that in the suburbs. Throughout the whole process of suburbanization in the United States, suburban sprawl caused not only a waste of land resources, but also (more seriously) enormous damage to the ecological environment. This damage included pollution of the atmosphere, water, and soil; destruction of the natural landscape; endangerment and extinction of wild animals and plants; and other negative outcomes [26]. However, considering the above comparative analysis, between the central urban areas and suburbs, despite certain changes in environmental quality in the suburbs, the quality remains better than that of the central urban areas in Shanghai. Thus, the overall environmental quality of Shanghai has improved. At present, the process of suburbanization in Shanghai does not have a significantly negative impact on the ecological environment of the suburbs, and the viewpoint of foreign scholars, that suburbanization is leading to ecological deterioration, has not been verified in Shanghai.

Edward Glaeser, a professor of economics at Harvard University, hypothesized that the carbon emissions of Americans living in sparsely populated suburbs with shady green trees, were far higher than those of people living in the central urban areas dominated by high-rise buildings. In fact, the average household carbon emissions in the central urban areas of New York were far lower than that in other suburbs. Therefore, Glaeser concluded that skyscrapers were more environmentally friendly than buildings in the countryside [82]. This conclusion represents a bold new viewpoint. In general, fossil fuel combustion, industrial production processes, agriculture and forestry, and other forms of land use/waste, are the four sources of greenhouse gas emissions; fossil fuel combustion is the main source of additional greenhouse gases. In 2010, the total energy consumption based on fossil fuel combustion in Shanghai was 6.33 million tons in the central urban areas, and 20.99 million equivalent tons of coal in the suburbs. The per capita coal consumption intensity in the central urban areas and suburbs was approximately 0.9069 tons and 1.3085 tons, respectively; the former was slightly lower than the latter. However, in terms of unit-area coal consumption intensity, which reached 21.870 thousand tons $/ \mathrm{km}^{2}$ per year in the central urban areas and 3.469 thousand tons $/ \mathrm{km}^{2}$ per year in the suburbs, the former was approximately 6.3 times that of the latter. If building energy consumption, transportation energy consumption, land use carbon emissions, human body heat extraction, and other factors are included, per capita energy consumption intensity or per capita carbon emission in the central urban areas might not be lower than in the suburbs. In addition, considering the significantly positive correlation between coal consumption intensity and carbon emission intensity, the general conclusion that skyscrapers are more environmentally friendly than the countryside, is biased towards only per capita carbon emission and energy consumption intensity.

Traditionally, environmental pollution is only an urban problem, and is not an issue for suburban populations. In other words, the negative effects of urban spread (air pollution, traffic jams, etc.) mainly appear in the center of the city, not in the suburbs. However, due to the driving of industrialization, urbanization, and globalization, the economic development speed of the outskirts is faster than that of the urban center, and the environmental pollution has become an increasing suburban problem. Therefore, we shall start from the city center and suburbs interactive evolution perspective in order to examine the environmental pollution problem, and the urbanizing urban political ecology will also give us inspiration [83,84]. In China, the government undertakes the development strategy of urban suburbanization, such as industrial suburbanization transfer, development zones, and new town construction, which causes urban suburbanization in China to passively evolve. In this process, many problems occur, such as idle land resources and inefficient land use, backward infrastructure, traffic congestion, and ecological environment destruction. Therefore, the city government should conscientiously study the rules and dynamic mechanisms of suburbanization, strengthen the macro guiding role of the government, focus on system innovation and public participation, and vigorously 
solve the problems of suburban land, infrastructure, ecological environment, security, etc., in order to promote the optimization of the economic, social, and ecological benefits of suburbanization.

\section{Conclusions and Suggestions}

The annual daily mean concentrations of $\mathrm{SO}_{2}, \mathrm{NO}_{2}$, and $\mathrm{PM}_{10}$ first increase, and then decrease, in the suburbs, but consistently decrease in central urban areas, largely because of industrial transfer in the central city and rapid industrial development in the suburbs. In addition, unreasonable emissions in the past have caused the soil to become polluted with heavy metals in the central city and have increased water quality pollution in Shanghai. Suburbanization has certainly caused changes in the quality of the ecological environment; however, currently, the overall environmental quality in the suburbs of Shanghai remains superior to that in the central urban areas. The viewpoint that suburbanization causes ecological disasters exaggerates the negative effects of the metropolis' suburbanization. Therefore, we should not exaggerate the negative impact of suburbanization on the quality of the surrounding ecological environment, and great attention must be given to controlling environmental pollution by industrial, population, and residential suburbanization.

Per capita carbon emissions produced by the registered population in central urban areas are generally lower than those in the suburbs, but the net carbon source per unit area in the central urban areas is generally higher than in the suburbs. Moreover, the core area emissions are much higher overall than the periphery of the central urban areas, the periphery of the central urban areas is higher than that of the inner suburbs, and those for the inner suburbs are higher than those for the outer suburbs. These results reveal a diminishing trend gradient. Additionally, the distribution of net carbon source per unit GDP is more complicated and lacks clear spatial laws. Therefore, the conclusion that skyscrapers are more environmentally friendly than the countryside is biased, only reflecting the per capita carbon emission.

The great disparities in national conditions and institutional structure mean that the suburbanization of Chinese metropolises is not following the same destructive path of the United States. Since suburbanization processes are being guided by sustainable development strategies, government decisions, and urban planning, suburbanization will probably not cause the decline of central urban areas, and spatial management and the control of growth will help curb suburban sprawl. Guided by sustainable development strategies and the creation of integrated management and control systems (including ecological protection boundaries, prime farmland protection boundaries, and control of land growth boundaries for construction and industry), the suburbanization of Chinese metropolises can avoid a fixed pattern of sprawl and forge a unique path of development involving intensive land use, clustered industries, cities and towns, and concern for the environment.

The improvement and promotion of urban and rural ecological environmental quality requires extensive interaction and cooperation among citizens and intergovernmental, inter-regional, and inter-enterprise agencies. The cross-regional, public, and external nature of ecological environmental problems means that the only approach which should be used for a true resolution of ecological crises, is one which will establish systematic and extensive cooperation mechanisms between citizens and intergovernmental, inter-regional, and inter-enterprise agencies. Any unilateral efforts are likely to be met with difficulty.

Acknowledgments: We are very grateful to the referees and the editors for their helpful suggestions. This paper is partially funded by the National High-tech R\&D Program of China (863 Program) (2015AA123901), the Education Department of Hebei Province (QN2016236) and the Doctoral Foundation of Hebei University of Engineering (No. 20120149).

Author Contributions: All of the authors contributed to the work in the paper. Hefeng Wang and Yishao Shi designed the research and wrote the paper. Anbing Zhang provided advice and suggestions and improved language. Yuan Cao and Haixin Liu contributed data collecting and preprocessing.

Conflicts of Interest: The authors declare no conflicts of interest. 


\section{References}

1. Mills, E.S.; Price, R. Metropolitan suburbanization and central city problems. J. Urban Econ. 1984, 15, 1-17. [CrossRef]

2. Williamson, M.; Walter-Joseph, R. How Suburban Ways of Living are Shaping the Geography of Income in Canadian Cities. LSE US Centre Blog. Available online: http://blogs.lse.ac.uk/usappblog/2015/07/21/ howsuburbanwaysoflivingareshapingthegeographyofincomeinCanadian-cities/ (accessed on 21 July 2015).

3. Phelps, N.A.; Wu, F. International Perspectives on Suburbanization. Nat. Publ. Group 2013, 42, $268-269$.

4. Hamel, P.; Keil, R. Suburban Governance: A Global View; University of Toronto Press: Toronto, ON, Canada, 2015; pp. 57-152.

5. Webster, D.R.; Cai, J.; Muller, L.; Luo, B. Emerging Third Stage Peri-Urbanization: Functional Specialization in the Hangzhou Peri-Urban Region. 2003. Available online: https://www.researchgate.net/publication/ 265047734_Emerging_Third_Stage_Peri-Urbanization_Functional_Specialization_in_the_Hangzhou_PeriUrban_Region (accessed on 1 January 2003).

6. Notice of the Shanghai Municipal People's Government on Printing and Distributing the Shanghai Main Functional Area Planning. Available online: http://govinfo.nlc.gov.cn/shfz/xxgk/shs/201302/t20130205_ 3444869.shtml (accessed on 5 February 2013). (In Chinese)

7. Li, J.L.; Cao, M.M. Impacts of Suburbanization on Urban Eco-environment in Xi'an City. Bull. Soil Water Conserv. 2005. (In Chinese) [CrossRef]

8. Fisher, A.B.; Dubois, A.B.; Hyde, R.W. Eco-Environmental Impact and Countermeasure of Suburbanization on Suburbs in Beijing. Environ. Prot. 2004, 34, 139-146.

9. Zou, Z. Study on the Spatial Measures for Suburbanization of Residential Areas in Big Cities. Planners 2004, 20, 94-96. (In Chinese)

10. Mieszkowski, P.; Mills, E.S. The Causes of Metropolitan Suburbanization. J. Econ. Perspect. 1993, 7, $135-147$. [CrossRef]

11. Kahn, M.E. The environmental impact of suburbanization. J. Policy Anal. Manag. 2000, 19, 569-586. [CrossRef]

12. Liu, Y.Y. Suburbanization of the United States and Its Implications to the Urban Efficient Growth of China. Sci. Geogr. Sin. 2011, 31, 891-896. (In Chinese)

13. Petr, K.; Pavel, R.; Zdenek, O.; Martina, N.; Szymanska, D. Suburbanization and Local Governance-Positive and Negative Forms: Olomouc Case Study. Bull. Geogr. Soc.-Econ. Ser. 2015, 27, 95-107.

14. Ma, Q.; Zhang, W.C. Characteristics and factors analyses of suburbanization in Beijing. Geogr. Res. 2006, 25, 121-130. (In Chinese)

15. Feng, J.; Zhou, Y.; Wu, F. New Trends of Suburbanization in Beijing since 1990: From Government-led to Market-oriented. Reg. Stud. 2008, 42, 83-99. (In Chinese) [CrossRef]

16. Zhou, Y.; Ma, L.J.C. Economic Restructuring and suburbanization in China. Urban Geogr. 2000, 21, $205-236$. (In Chinese) [CrossRef]

17. Wang, C.; Yang, S. Dynamic Analysis on Population Suburbanization and New Town Development in Shanghai. China City Plan. Rev. 2016, 2, 70-75.

18. Wu, Y. Study on Urban Spatial Structure Optimization in the Process of Shanghai's Suburbanization. J. Tongji Univ. Soc. Sci. 2010, 21, 45-53. (In Chinese)

19. Lovaas, D. Suburbanization and Energy. Encycl. Energy 2004, 37, 765-776.

20. Jiang, G.; Ma, W.; Qu, Y.; Zhang, R.; Zhou, D. How does sprawl differ across urban built-up land types in China? A spatial-temporal analysis of the Beijing metropolitan area using granted land parcel data. Cities 2016, 58, 1-9. [CrossRef]

21. Yue, W.; Liu, Y.; Fan, P. Measuring Urban Sprawl and Its Drivers in Large Chinese Cities: The Case of Hangzhou. Land Use Policy 2013, 31, 358-370. [CrossRef]

22. Tian, L.; Ge, B.; Li, Y. Impacts of state-led and bottom-up urbanization on land use change in the peri-urban areas of Shanghai: Planned growth or uncontrolled sprawl? Cities 2017, 60, 476-486. [CrossRef]

23. Vojnovic, I.; Darden, J.T. Class/racial conflict, intolerance, and distortions in urban form: Lessons for sustainability from the Detroit region. Ecol. Econ. 2013, 96, 88-98. [CrossRef]

24. Lau, J.C.Y. The influence of suburbanization on the access to employment of workers in the new towns: A case study of Tin Shui Wai, Hong Kong. Habitat Int. 2010, 34, 38-45.

25. Yang, M.; Wang, Y.B.; Fu, Q.Q. Urban growth pains. Decision-Making 2012, 9, 5-17. (In Chinese) 
26. Berlin, C. Sprawl Comes to the American Heartland. Focus Geogr. 2010, 46, 2-9. [CrossRef]

27. Wu, K. "Ghost city": Religion, urbanization and spatial anxieties in contemporary China. Geoforum 2015, 65, 243-245. [CrossRef]

28. Chen, M.; Liu, W.; Lu, D. Challenges and the way forward in China's new-type urbanization. Land Use Policy 2015, 55, 334-339. [CrossRef]

29. Oro, A.M. The Triumph of the City: How Our Greatest Invention Makes Us Richer, Smarter, Greener, Healthier, and Happier. Soc. J. 2013, 31, 120-122.

30. Berry, B.J.L. Comparative Urbanisation: Divergent Paths in the Twentieth Century; Macmillan: London, UK, 1981.

31. Shanghai Municipal Statistics Bureau. The Shanghai Statistical Yearbook; China Statistics Press: Beijing, China, 1998. (In Chinese)

32. Shanghai Municipal Statistics Bureau. The Shanghai Statistical Yearbook; China Statistics Press: Beijing, China, 1999. (In Chinese)

33. Shanghai Municipal Statistics Bureau. The Shanghai Statistical Yearbook; China Statistics Press: Beijing, China, 2000. (In Chinese)

34. Shanghai Municipal Statistics Bureau. The Shanghai Statistical Yearbook; China Statistics Press: Beijing, China, 2001. (In Chinese)

35. Shanghai Municipal Statistics Bureau. The Shanghai Statistical Yearbook; China Statistics Press: Beijing, China, 2002. (In Chinese)

36. Shanghai Municipal Statistics Bureau. The Shanghai Statistical Yearbook; China Statistics Press: Beijing, China, 2003. (In Chinese)

37. Shanghai Municipal Statistics Bureau. The Shanghai Statistical Yearbook; China Statistics Press: Beijing, China, 2004. (In Chinese)

38. Shanghai Municipal Statistics Bureau. The Shanghai Statistical Yearbook; China Statistics Press: Beijing, China, 2005. (In Chinese)

39. Shanghai Municipal Statistics Bureau. The Shanghai Statistical Yearbook; China Statistics Press: Beijing, China, 2006. (In Chinese)

40. Shanghai Municipal Statistics Bureau. The Shanghai Statistical Yearbook; China Statistics Press: Beijing, China, 2007. (In Chinese)

41. Shanghai Municipal Statistics Bureau. The Shanghai Statistical Yearbook; China Statistics Press: Beijing, China, 2008. (In Chinese)

42. Shanghai Municipal Statistics Bureau. The Shanghai Statistical Yearbook; China Statistics Press: Beijing, China, 2009. (In Chinese)

43. Shanghai Municipal Statistics Bureau. The Shanghai Statistical Yearbook; China Statistics Press: Beijing, China, 2010. (In Chinese)

44. Shanghai Municipal Statistics Bureau. The Shanghai Statistical Yearbook; China Statistics Press: Beijing, China, 2011. (In Chinese)

45. Shanghai Municipal Statistics Bureau. The Shanghai Statistical Yearbook; China Statistics Press: Beijing, China, 2012. (In Chinese)

46. Shanghai Municipal Statistics Bureau. The Shanghai Statistical Yearbook; China Statistics Press: Beijing, China, 2013. (In Chinese)

47. Shanghai Municipal Statistics Bureau. The Shanghai Statistical Yearbook; China Statistics Press: Beijing, China, 2014. (In Chinese)

48. Shanghai Environmental Protection Bureau. The Shanghai Bulletins of Environmental Quality; Shanghai Environmental Protection Bureau: Shanghai, China, 1998. (In Chinese)

49. Shanghai Environmental Protection Bureau. The Shanghai Bulletins of Environmental Quality; Shanghai Environmental Protection Bureau: Shanghai, China, 1999. (In Chinese)

50. Shanghai Environmental Protection Bureau. The Shanghai Bulletins of Environmental Quality; Shanghai Environmental Protection Bureau: Shanghai, China, 2000. (In Chinese)

51. Shanghai Environmental Protection Bureau. The Shanghai Bulletins of Environmental Quality; Shanghai Environmental Protection Bureau: Shanghai, China, 2001. (In Chinese)

52. Shanghai Environmental Protection Bureau. The Shanghai Bulletins of Environmental Quality; Shanghai Environmental Protection Bureau: Shanghai, China, 2002. (In Chinese) 
53. Shanghai Environmental Protection Bureau. The Shanghai Bulletins of Environmental Quality; Shanghai Environmental Protection Bureau: Shanghai, China, 2003. (In Chinese)

54. Shanghai Environmental Protection Bureau. The Shanghai Bulletins of Environmental Quality; Shanghai Environmental Protection Bureau: Shanghai, China, 2004. (In Chinese)

55. Shanghai Environmental Protection Bureau. The Shanghai Bulletins of Environmental Quality; Shanghai Environmental Protection Bureau: Shanghai, China, 2005. (In Chinese)

56. Shanghai Environmental Protection Bureau. The Shanghai Bulletins of Environmental Quality; Shanghai Environmental Protection Bureau: Shanghai, China, 2006. (In Chinese)

57. Shanghai Environmental Protection Bureau. The Shanghai Bulletins of Environmental Quality; Shanghai Environmental Protection Bureau: Shanghai, China, 2007. (In Chinese)

58. Shanghai Environmental Protection Bureau. The Shanghai Bulletins of Environmental Quality; Shanghai Environmental Protection Bureau: Shanghai, China, 2008. (In Chinese)

59. Shanghai Environmental Protection Bureau. The Shanghai Bulletins of Environmental Quality; Shanghai Environmental Protection Bureau: Shanghai, China, 2009. (In Chinese)

60. Shanghai Environmental Protection Bureau. The Shanghai Bulletins of Environmental Quality; Shanghai Environmental Protection Bureau: Shanghai, China, 2010. (In Chinese)

61. Shanghai Environmental Protection Bureau. The Shanghai Bulletins of Environmental Quality; Shanghai Environmental Protection Bureau: Shanghai, China, 2011. (In Chinese)

62. Shanghai Water Authority, Shanghai Municipal Ocean Brueau. Shanghai Water Resources Bulletin in 2012; Shanghai Water Authority, Shanghai Municipal Ocean Brueau: Shanghai, China, 2012. (In Chinese)

63. Shanghai Water Authority, Shanghai Municipal Ocean Brueau. Shanghai Water Resources Bulletin in 2013; Shanghai Water Authority, Shanghai Municipal Ocean Brueau: Shanghai, China, 2013. (In Chinese)

64. Shanghai Institute of Geological Survey. The Report of Shanghai Land Quality Monitoring (2009-2012); Shanghai Institute of Geological Survey: Shanghai, China, 2013. (In Chinese)

65. Shanghai Institute of Geological Survey. The Second Shanghai Land Survey Database; Shanghai Institute of Geological Survey: Shanghai, China, 2009. (In Chinese)

66. Ji, X.Y.S.; Kang, S.R.; Yu, Y.J.L.; Chien, W.T.K. A study on the statistical comparison methods for engineering applications. In Proceedings of the IEEE International Conference on Industrial Engineering and Engineering Management, Bangkok, Thailand, 10-13 December 2013; pp. 576-580.

67. Fabbro, R.; Delorme, R.; Arnoud, Y.; Adam, J.F.; Boyer, B.; Gallin-Martel, L.; Gallin-Martel, M.L.; Rossetto, O.; Fonteille, I.; Giraud, J.Y. 54-Simulation of the head of an accelerator: Calculation optimization and statistical comparison methods. Phys. Med. 2015, 31, e43-e44. [CrossRef]

68. Field, C.B.; Mortsch, L.D.; Brklacich, M.; Forbes, D.L.; Kovacs, P.; Patz, J.A.; Running, S.W.; Scott, M.J. North America. Climate Change 2007: Impacts, Adaptation and Vulnerability: Contribution of Working Group II to the fourth assessment report of the Intergovernmental Panel on Climate Change. Contribution of Working Group II to the Third Assessment Report. 2007. Available online: https://works.bepress.com/david_sailor/31/ (accessed on 1 January 2007).

69. Richter, D.D.; Markewitz, D.; Trumbore, S.E.; Wells, C.G. Rapid accumulation and turnover of soil carbon in a re-establishing forest. Nature 1999, 400, 56-58. [CrossRef]

70. Bellamy, P.H.; Loveland, P.J.; Bradley, R.I.; Lark, R.M.; Kirk, G.J. Carbon losses from all soils across England and Wales 1978-2003. Nature 2005, 437, 245-248. [CrossRef] [PubMed]

71. Melillo, J.M.; Reilly, J.M.; Kicklighter, D.W.; Gurgel, A.C.; Cronin, T.W.; Paltsev, S.; Felzer, B.S.; Wang, X.; Sokolov, A.P.; Schlosser, C.A. Indirect emissions from biofuels: How important? Science 2009, 326, 1397-1399. [CrossRef] [PubMed]

72. Steinkamp, K.; Gruber, N. A joint atmosphere-ocean inversion for the estimation of seasonal carbon sources and sinks. Glob. Biogeochem. Cycles 2013, 27, 732-745. [CrossRef]

73. Penman, J. Good Practice Guidance and Uncertainty Management in National Greenhouse Gas Inventories. D Cycleence \& Management Kruger I Galbally T Hiraishi B Nyenzi. 2000. Available online: http:/ /www. wbcsdcement.org/pdf/tf1/Table_of_contents.pdf (accessed on 15 June 2001).

74. Fang, J.Y.; Guo, Z.D.; Shilong, P.; Chen, A.P. Terrestrial vegetation carbon sinks in China, 1981-2000. Sci. China 2007, 50, 1341-1350. [CrossRef]

75. Qian, X.Y. Spatial-temporal Variation and Impact Factor of Carbon Source and Sink of Farmland Ecosystem in Shanghai, China. J. Agro-Environ. Sci. 2011, 30, 1460-1467. (In Chinese) 
76. Guo, R.; Cao, X.; Yankuan, L.I.; Fengting, L.I. Shanghai's Strategies for Carbon Emission Reduction as a Response to Climate Change. J. Tongji Univ. 2009, 37, 515-519. (In Chinese)

77. Lal, R. Soil carbon sequestration impacts on global climate change and food security. Science 2004, 304, 1623-1627. [CrossRef] [PubMed]

78. Duan, X.N.; Fei, X.K. Carbon sequestration and its potential by wetland ecosystems in China. Acta Ecol. Sin. 2008, 28, 463-469. (In Chinese)

79. Mei, X.Y.; Zhang, X.F. Carbon storage and fixation by a typical wetland vegetation in Changjiang River Estuary-A case study of Phragmites australis in east beach of Chongming Island. Chin. J. Eco-Agric. 2008, 16, 269-272. (In Chinese)

80. Zhou, S.Z. Five islands effect of urban climate in Shanghai. Sci. China Ser. B 1990, 1, 67-78.

81. Yang, H.; Huang, X.; Thompson, J.R.; Flower, R.J. Soil Pollution: Urban Brownfields. Science 2014, 344, 691-692. [CrossRef] [PubMed]

82. Glaeser, E.L.; Kahn, M.E. The greenness of cities: carbon dioxide emissions and urban development. J. Urban Econ. 2010, 67, 404-418. [CrossRef]

83. Angelo, H.; Wachsmuth, D. Urbanizing Urban Political Ecology: A Critique of Methodological Cityism. Int. J. Urban Reg. Res. 2015, 39, 16-27. [CrossRef]

84. Wachsmuth, D.; Cohen, D.A.; Angelo, H. Expand the frontiers of urban sustainability. Nature 2016, 536, 391-393. [CrossRef] [PubMed]

(C) 2017 by the authors; licensee MDPI, Basel, Switzerland. This article is an open access article distributed under the terms and conditions of the Creative Commons Attribution (CC-BY) license (http://creativecommons.org/licenses/by/4.0/). 